\title{
Upaya rehabilitasi DAS Citarum dengan desain lanskap (studi kasus: bantaran sungai Citarum Desa Bojongsoang, Bandung dan Desa Purwadana, Karawang)
}

\author{
Wasissa Titi llhami1 dan Andy Affandy² \\ 1. Dosen Sekolah Tinggi Penyuluhan Pertanian Bogor, Indonesia \\ 2. Peneliti Bid. Pengelolaan Sumberdaya Alam dan Lingkungan, PKSPL-IPB, Indonesia \\ *E-mail: wasissatitie@gmail.com
}

\begin{abstract}
Landscape design employment to Citarum watershed rehabilitation (case study in Bojongsoang Village, Bandung Regency and Purwadana Village, Karawang Regency). Citarum watershed in Karawang and Bandung Regencies is a prone flooding area. An ideal landscape planning is required to manage this watershed area. It should be a conservation area that can be used by the community in surrounding both for recreation purpose when there is no flood and as a pick up point purpose during the flood. This research aimed to create technical design for the rehabilitation effort of river in Purwadana Village, Karawang Regency and Bojongsoang Village, Bandung Regency. It is expected that it can be used as an alternative design that can make people more adaptive to flood disaster. The management of watershed can be used for conservation area and river tourism. This tourism aims to make people care to their environment, to grow their sense of belonging to jointly maintain and conserve the river around their livelihood. Methods used in this research were survey method, land suitability analysis, interview, and literature study. The research results showed that according to the ecological analysis and ideal landscape approach for watershed area, this Citarum Watershed area is suitable for tourism site.
\end{abstract}

Keywords: flood, riparian rehabilitation, landscape design, tourism

\section{Pendahuluan}

Pertumbuhan penduduk sejalan dengan kebutuhan tingkat tinggal. Sebagian orang menggunakan ruang yang masih tersisa yaitu di bantaran dan badan sungai sebagai tempat tinggal, perdagangan, perkantoran, industri dan sebagainya. Akibatnya, hal tersebut memberikan dampak negatif terhadap lanskap sungai seperti keseimbangan ekosistem terganggu dan menyebabkan fungsi sungai pun berubah. (Widodo,2012). Kondisi iklim di Indonesia adalah tropis dengan dua musim yaitu musim hujan dan musim kemarau. Perubahan musim tersebut dapat memberi dampak yang berbeda di kawasan bantaran sungai. Saat musim hujan, dampak negatif yang terjadi adalah bencana banjir dan tanah longsor, sedangkan saat musim kemarau biasanya dampaknya adalah sungai menjadi kering dan justru sering dimanfaatkan untuk lahan pertanian. Selain perubahan musim banjir juga dapat terjadi karena perubahan dan pengelolaan penggunaan lahan yang tidak tepat (Woube, 1999), sedangkan perubahan penggunaan lahan bersifat dinamis terhadap besarnya debit aliran sebagai respon terhadap curah hujan (Asdak, 2010). Akibat dari hal tersebut, apabila curah hujan tinggi dan tanah sudah tidak mampu menyerap air karena berkurangnya daerah resapan air dan saluran sungai yang tidak mampu menampung kelebihan limpasan air maka terjadilah banjir.

Bantaran Sungai Citarum di Kabupaten Karawang dan Bandung merupakan kawasan yang rawan terjadi banjir. Upaya pencegahan yang dilakukan adalah dengan mengedukasi warga dengan pengetahuan tentang DAS (Daerah Aliran Sungai). DAS (Daerah Aliran Sungai) merupakan daerah resapan air yang dapat mengatur sistem tata air. Secara alami kualitas DAS dipengaruhi oleh faktor biofisik pembentuk tanah yaitu relief, topografi, fisiografi, iklim, tanah, air dan vegetasi (Komaruddin, 2008). Selain itu, DAS merupakan suatu wilayah kesatuan ekosistem yang dibatasi oleh pemisah topografis dan berfungsi sebagai tempat aktivitas dan perlindungan alam (hidrologi, konservasi plasma nutfah, dan sebagainya) mana aliran air atau sungai akan keluar melalui suatu outlet tunggal (Haridjaja, 2008). 
Rehabilitasi riparian merupakan program yang sangat penting untuk meningkatkan infiltrasi air dan menjaga keanekaragaman hayati di ekosistem riparian (sekitar badan air). Peningkatan infiltrasi air akan mengurangi erosi dan sedimentasi, yang dapat meminimalkan dampak banjir saat musim hujan dan untuk mencegah kekeringan pada musim kemarau. Dalam penelitian ini, yang dilakukan adalah mengidentifikasi lokasi dan menciptakan desain lanskap sebagai upaya rehabilitasi sungai hingga diketahui desain yang yang paling ideal. Wisata sungai menjadi solusi dan output dalam penelitian ini. Selain karena dengan wisata dapat bermanfaat untuk masyarakat bantaran sungai juga karena tepi sungai adalah fitur air yang paling menarik bagi pemukiman manusia, bahkan di sebagian besar negara, tanah di depan air dikembangkan lebih awal dari daerah pedalaman (Zhang, 2002). Salah satu fungsi sosial sungai yang cukup dikenal adalah sebagai bagian dari potensi wisata (Prideaux and Cooper, 2009), untuk kondisi Indonesia sendiri, wisata sungai masih belum banyak diminati. Padahal, Indonesia punya beberapa sungai yang bisa diberdayakan untuk meningkatkan pariwisata. Keberadaan sungai di negara tropis seperti Indonesia punya keunikan tersendiri. Sungai dengan air cenderung hangat ini melewati hutan tropis, menjadi ekosistem bagi flora dan fauna khas Negeri Khatulistiwa seperti yang terdapat pada bantaran sungai Citarum pada penelitian ini. Tujuan dari penelitian ini adalah menghasilkan desain lanskap sebagai upaya rehabilitasi sungai di Desa Purwadana Kabupaten Karawang dan Desa Bojongsoang, Kabupaten Bandung.

\section{Metode Penelitian}

\subsection{Waktu dan Lokasi Penelitian}

Penelitian ini dilakukan di bantaran Sungai Citarum yaitu di Kabupaten Bandung (Desa Bojongsoang) dan Kabupaten Karawang (Desa Purwadana) mulai bulan Juni sampai bulan Desember 2016.

\subsection{Metode dan Tahapan Penelitian}

\subsubsection{Persiapan}

Diawali dengan survey untuk menentukan lokasi pelaksanaan penelitian melalui metode skoring dan analisis kesesuaian lahan secara deskriptif

\subsubsection{Pengumpulan data}

data biofisik mengenai kondisi tapak, aspek sosial, ekonomi, budaya dan data pendukung lain yang mempengaruhi proses perencanaan lanskap kawasan Sungai Citarum. Untuk pengumpulan data dilakukan dengan dua cara, yaitu survey lapang dan studi pustaka.

\subsubsection{Analisis dan Sintesis}

Data dan informasi yang didapat dianalisis secara deskriptif kuantitatif dan dalam bentuk spasial.

\subsubsection{Perencanaan Lanskap}

Berupa penyusunan konsep desain lanskap yang kemudian dikembangkan dalam bentuk rencana ruang, sirkulasi, tata hijau, aktivitas dan tata fasilitas yang dituangkan dalam bentuk rencana lanskap (landscape plan) secara tertulis dan tergambar.

\subsubsection{Perancangan Desain Lanskap}

Berupa penyusunan siteplan, ilustrasi perspektif, Rencana Penanaman, Desain Tehnik bioEngineering (retaining wall, groyne, retention pond),

\section{Hasil dan Pembahasan}

Desain lanskap yang ditawarkan adalah penataan sempadan sungai yang dimanfaatkan selain untuk area konservasi juga untuk wisata sungai. Wisata yang dilakukan disini bertujuan untuk membuat masyarakat lebih peduli dengan lingkungannya, menumbuhkan sense of belonging agar bersama-sama menjaga dan mengkonservasi sungai disekitar mereka masing-masing.

Upaya teknis konservasi yang dilakukan dalam menangani kondisi lanskap dikedua kawasan tersebut diantaranya:

1) Pengerukan/pendalaman sungai merupakan upaya untuk mengurangi sedimentasi sungai, memperbesar daya tampung air

2) Penambahan tanggul merupakan upaya pembangunan bangunan konservasi untuk melindungi kawasan pemukiman dari luapan banjir. 
3) Revegetasi merupakan penanaman tanaman konservasi yang sesuai dengan ekosistem sungai kedua desa.

4) Penambahan kolam retensi merupakan upaya untuk menampung air yang berlebih saat banjir

5) Pembangunan groyne merupakan upaya pembangunan bangunan konservasi untuk mengurangi laju air.

\subsection{Perencanaan Desain Lanskap Sempadan Sungai di Desa Bojongsoang, Kabupaten Bandung}

Sempadan sungai di desa Bojongsoang, Kabupaten Bandung secara umum sudah banyak dimanfaatkan oleh masyarakat sekitar. Hal itu terlihat dari adanya lahan yang dimanfaatkan sebagai lahan pertanian. Khususnya tanaman perladangan seperti jagung dan sayur-sayuran. Pohon yang terdapat di sepanjang bantaran sungai kebanyakan belum merupakan pohon konservasi yang sengaja ditanam untuk penanggulangan banjir, selain itu pertumbuhannya juga tidak cukup baik dikarenakan pemilihan jenis/species yang kurang sesuai. Penambahan tanggul dan retention pond direncanakan dilakukan untuk mencegah meluapnya banjir serta menampung debit air yang berlebihan.

Perencanaan desain lanskap yang dilakukan di sempadan sungai desa Bojongsoang mengambil tema Bojongsoang Waterpark. Konsep rehabilitasi sungai yang diterapkan adalah dengan memanfaatkan lanskap di sekitarnya untuk kegiatan publik seperti rekreasi disaat kondisi banjir maupun tidak. Masyarakat dapat berkunjung melakukan wisata air, menikmati udara dan kesejukan lingkungan sungai. Pada blockplan dibawah ini terlihat pembagian area yang terbagi menjadi 3 (tiga) yaitu :

a) welcome area merupakan area dimana terdapat gerbang untuk memasuki kawasan ini, fasilitas yang terdapat disana diantaranya, gerbang masuk dan kantor pengelola.

b) conservation area merupakan area dimana terdapat kawasan yang di revegetasi/ditanami kembali dengan menggunakan tanaman lokal yang sekaligus berfungsi untuk mengkonservasi sempadan sungai, penambahan pulau di tengah sungai yang berfungsi sebagai habitat satwa dan estetika untuk kawasan wisata.

c) public/recreation area merupakan area dimana terdapat bangunan publik berupa observation deck sebagai pick up point masyarakat saat banjir, kios, retention pond yang berfungsi selain untuk menampung kelebihan air juga untuk kolam rekreasi bagi masyarakat sekitar.

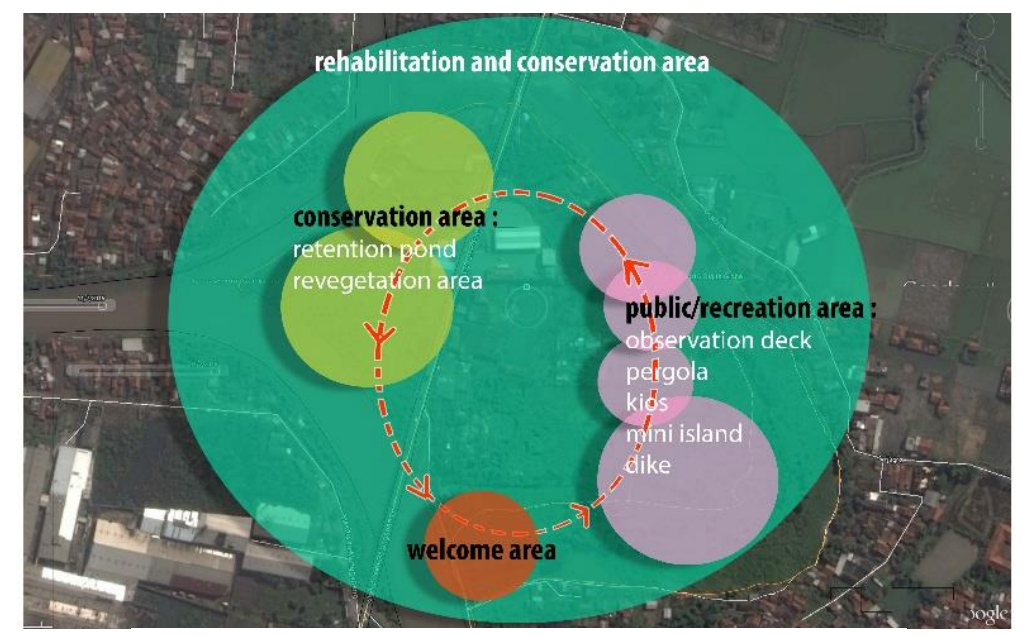

Gambar 1. Blockplan Bojongsoang, Bandung

Dari gambar blockplan diatas, kemudian diturunkan menjadi siteplan yang menggambarkan kondisi tapak setelah didesain. Pada siteplan Bojongsoang Waterpark ini terlihat observation/evacuation deck dengan pola desain yang bersambungan dengan pulau di tengah sungai. Konstruksi yang digunakan adalah beton untuk penampang bawahnya, serta menggunakan material kayu untuk decknya. Selain untuk sarana rekreasi, deck ini digunakan sebagai pick up point ketika terjadi banjir dan menjadi tempat berkumpul masyarakat, berekreasi menikmati pemandangan dan udara sejuk di sungai yang hijau dengan pohon dan asri dengan 
pohon berbunga yang indah. Sensansi pemandangan disaat banjir juga akan menjadi atraksi yang menarik untuk masyarakat ketika air datang.

llustrasi perspektif menunjukkan beberapa spot view yang terdapat di Bojongsoang waterpark, baik view dari tepi sungai, retention pond, observation deck dan aktivitas pengunjung yang sedang melakukan rekreasi cannoing menikmati arus sungai yang tenang ketika tidak ada indikasi akan datang hujan dan air yang meluap. Selain mendayung, pengunjung dapat menikmati kesejukan dari kolam retensi yang dibuat. Namun, kolam ini hanya dapat dinikmati ketika dalam kondidi normal/tidak banjir.

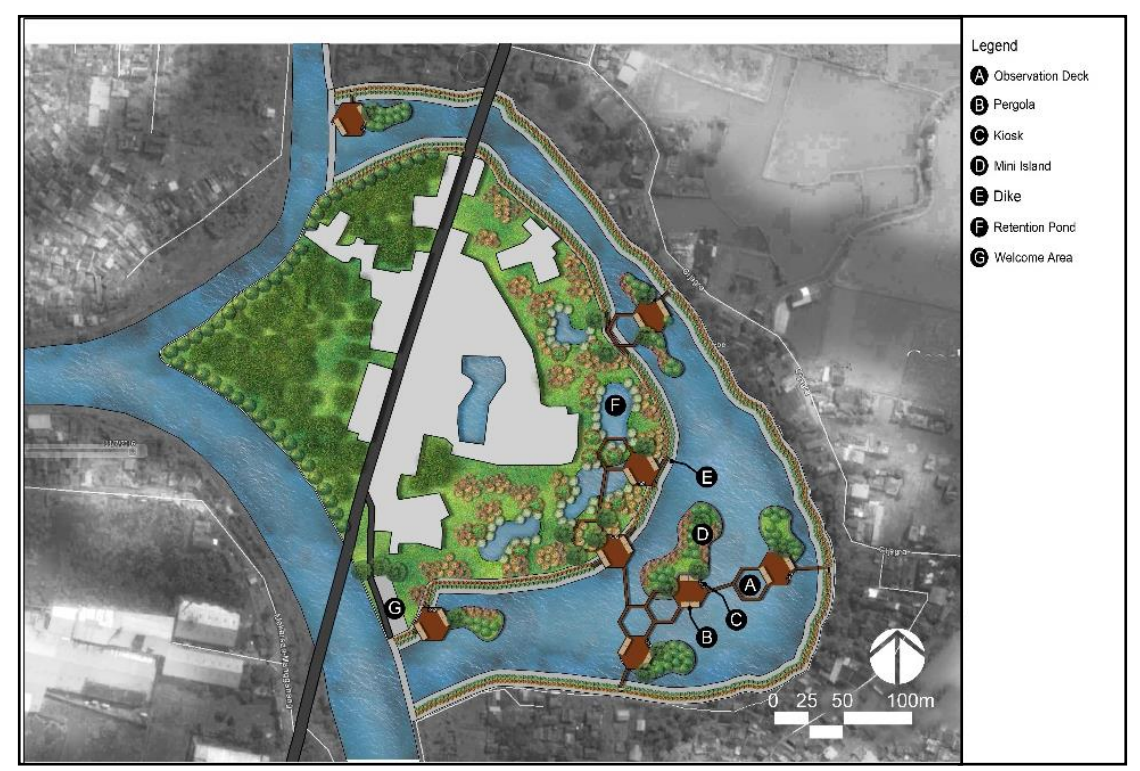

Gambar 2 . Siteplan Bojongsoang, Bandung

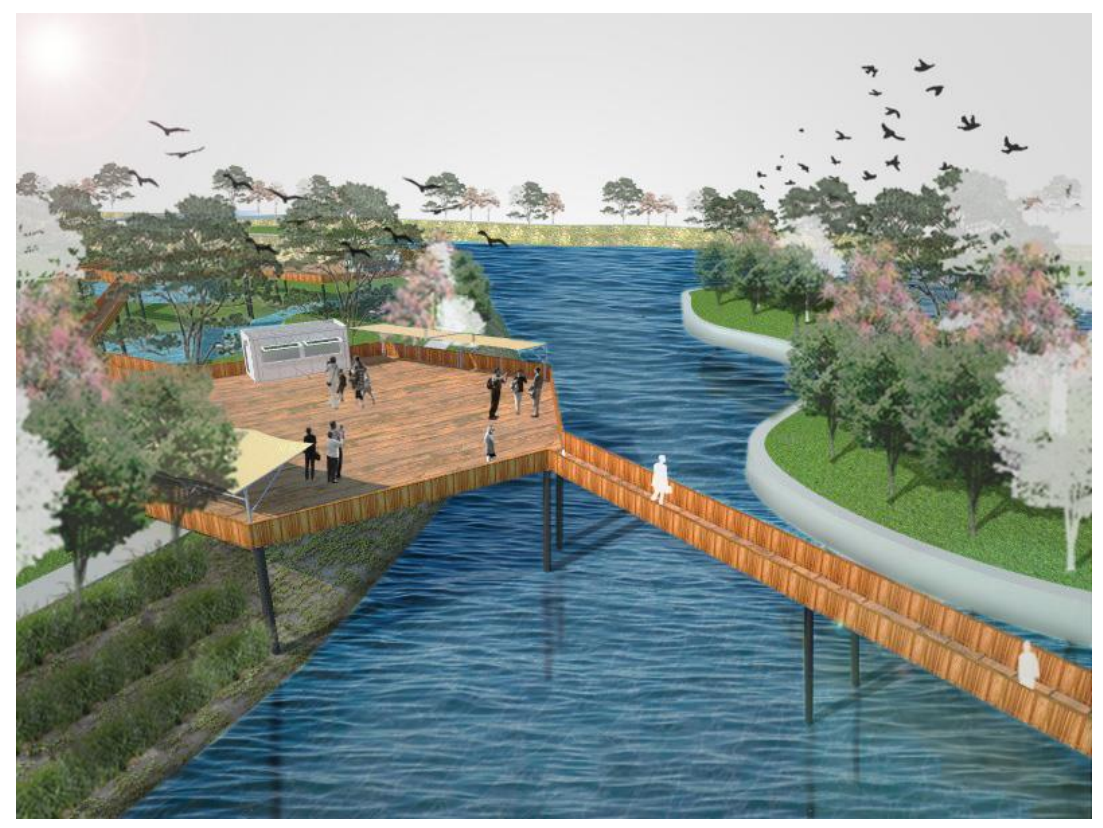

Gambar 3. Ilustrasi Perspektif : Deck Observasi dalam kondisi Normal 


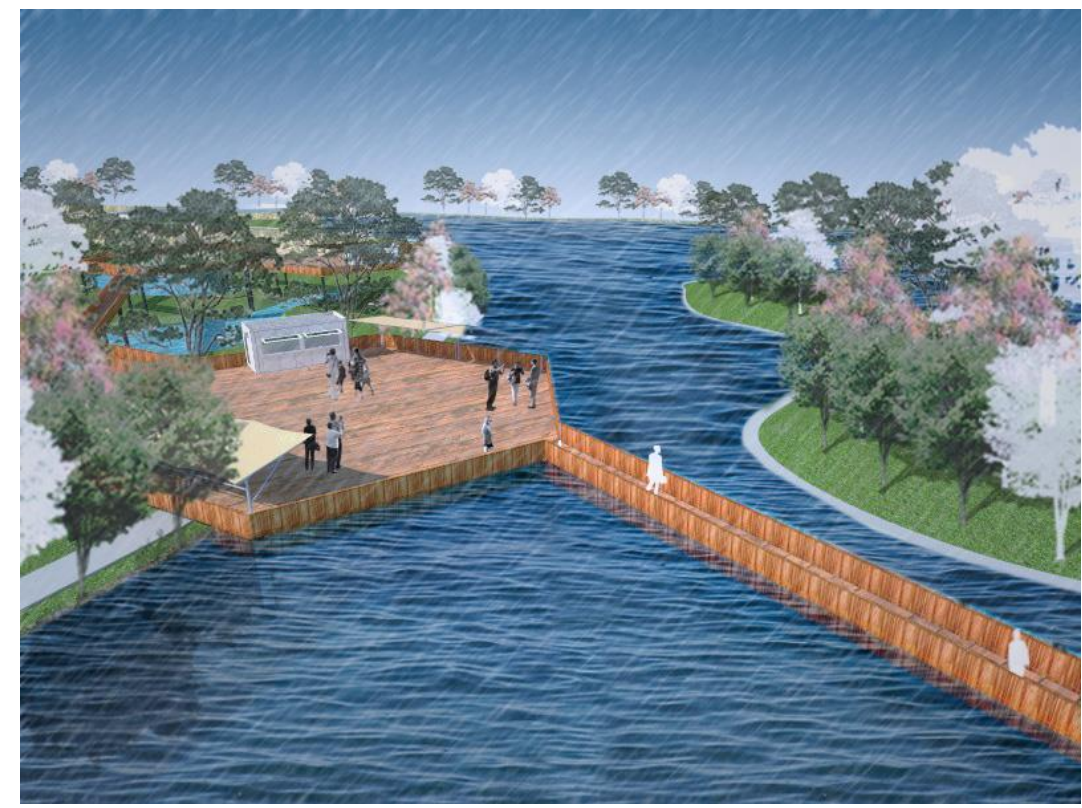

Gambar 4. Ilustrasi Perspektif : Deck Observasi kondisi Banjir

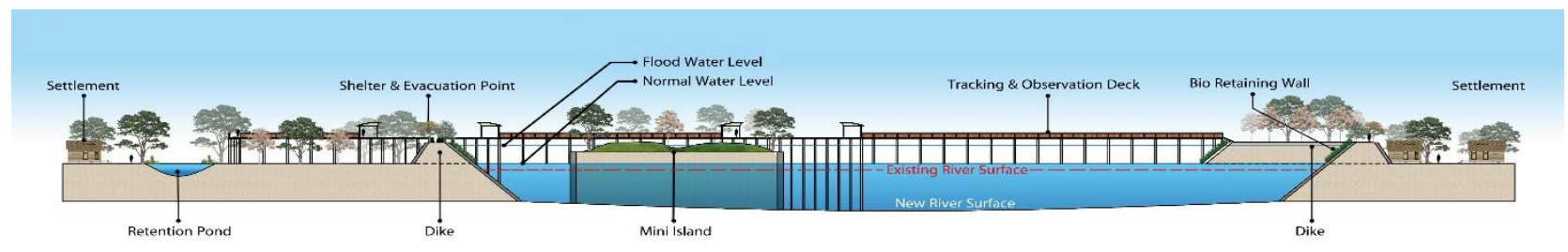

Gambar 5. Gambar Potongan oxbow Bojongsoang

\subsection{Perencanaan Desain Lanskap Sempadan Sungai di Desa Purwadana, Kabupaten Karawang}

Kondisi eksisting bantaran sungai Citarum di Kabupaten Karawang cukup potensial untuk dimanfaatkan sebagai kawasan pusat konservasi dan rehabilitasi sungai yang dipadukan dengan konsep rekreasi untuk masyarakat sekitar sungai. Bantaran sungai sepanjang tapak masih belum termanfaatkan dengan baik. Pohon yang terdapat di sepanjang bantaran sungai memang sebelumnya merupakan program dari beberapa instansi untuk penghijauan, namun pertumbuhannya tidak cukup baik dikarenakan pemilihan jenis/species yang kurang sesuai. Tanggul yang berada di pinggir sungai belum mampu untuk menahan air yang meluap, debit air yang terlalu besar juga kemungkinan disebabkan karena kedalaman sungai yang semakin dangkal karena sedimentasi. Penambahan tanggul dan groyne untuk mencegah laju air yang terlalu deras serta mengurangi debit air yang meluap.

Desain tematik di kawasan ini adalah Purwadana Waterpark. Konsep rehabilitasi sungainya adalah dengan pemanfaatan lanskap di sekitar bantaran sungai untuk kegiatan publik untuk rekreasi disaat kondisi banjir maupun tidak. Terlihat pada blockplan dibawah ini, pembagian area di kawasan ini terbagi menjadi 3 (tiga) yaitu :

a) welcome area merupakan area dimana terdapat gerbang untuk memasuki kawasan ini, fasilitas yang terdapat disana diantaranya, gerbang masuk dan kantor pengelola

b) conservation area merupakan area dimana terdapat kawasan yang di revegetasi/ditanami kembali dengan menggunakan tanaman lokal yang sekaligus berfungsi untuk mengkonservasi sempadan sungai serta kawasan yang ditanggul dan dipasang groyne. 
c)

public/recreation area merupakan area dimana terdapat bangunan publik berupa observation deck, amphitheatre, kios, retention pond yang berfungsi selain untuk menampung kelebihan air juga untuk kolam rekreasi bagi masyarakat sekitar.

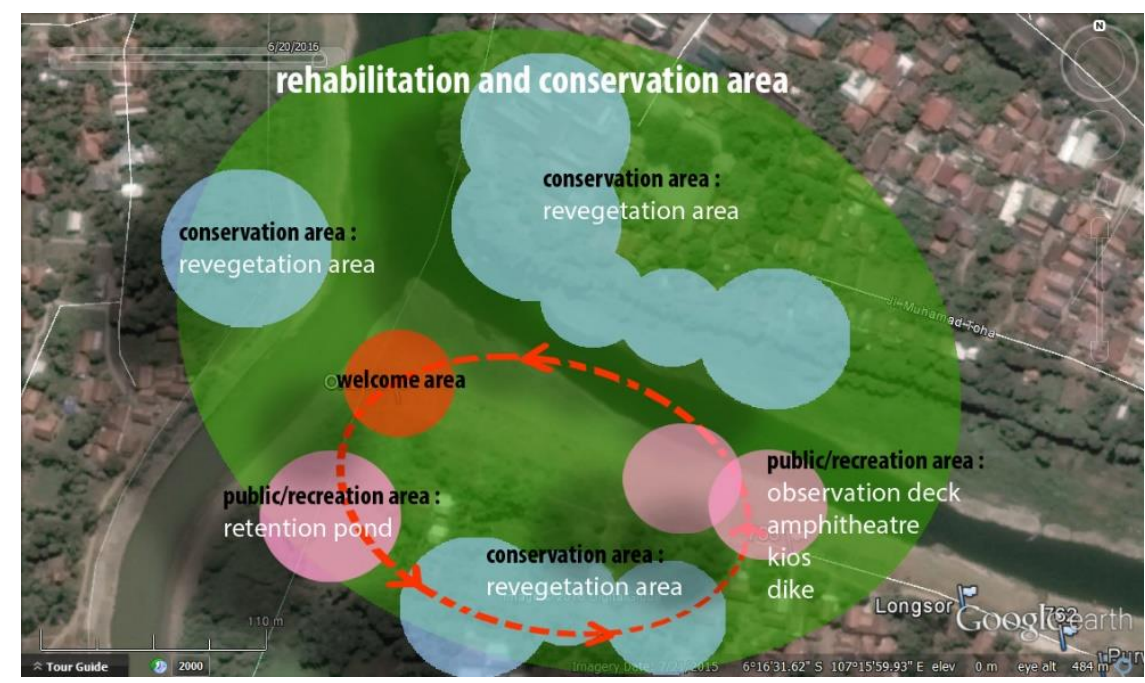

Gambar 6. Blockplan Purwadana, Karawang

Dari gambar blockplan diatas, kemudian diturunkan menjadi siteplan yang menggambarkan kondisi tapak setelah didesain yaitu Purwadana waterpark. Keunggulan lokasi purwadana park ini adalah adanya amphitheatre di pinggir sungai, yang bertujuan sebagai tempat berkumpul masyarakat, berekreasi menikmati pemandangan. Sensansi pemandangan disaat banjir juga akan menjadi atraksi yang menarik untuk masyarakat ketika air datang dan ketika sungai memiliki gelombang-gelombang kecil saat bertabrakan dengan groyne. Kanan kirinya dibangun bio-retainingwall di sepanjang tebing sungai. Selain itu terdapat observation deck dengan desain konstruksi menggunakan beton untuk penampang bawahnya, serta menggunakan material kayu untuk decknya. Selain untuk sarana rekreasi, deck ini digunakan sebagai pick up point ketika terjadi banjir dan ketika kondisi normal digunakan untuk jogging track dan bersepeda.

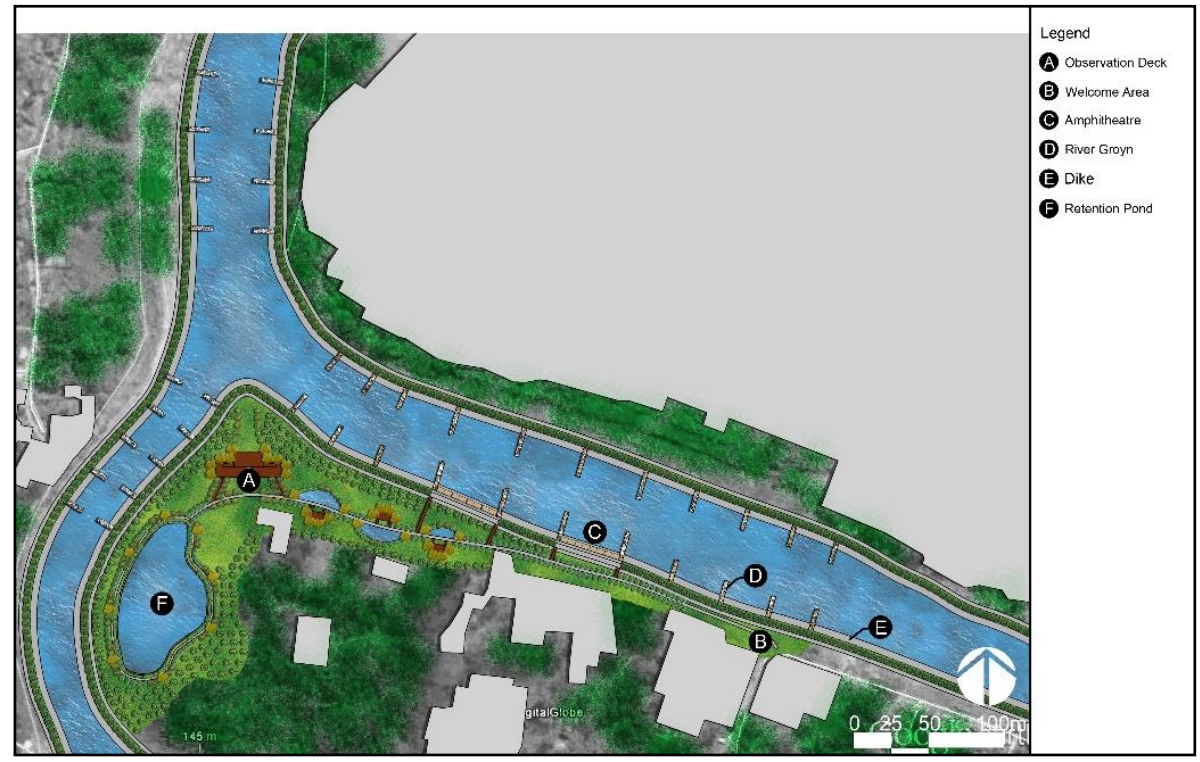

Gambar 7. Siteplan Purwadana, Karawang 


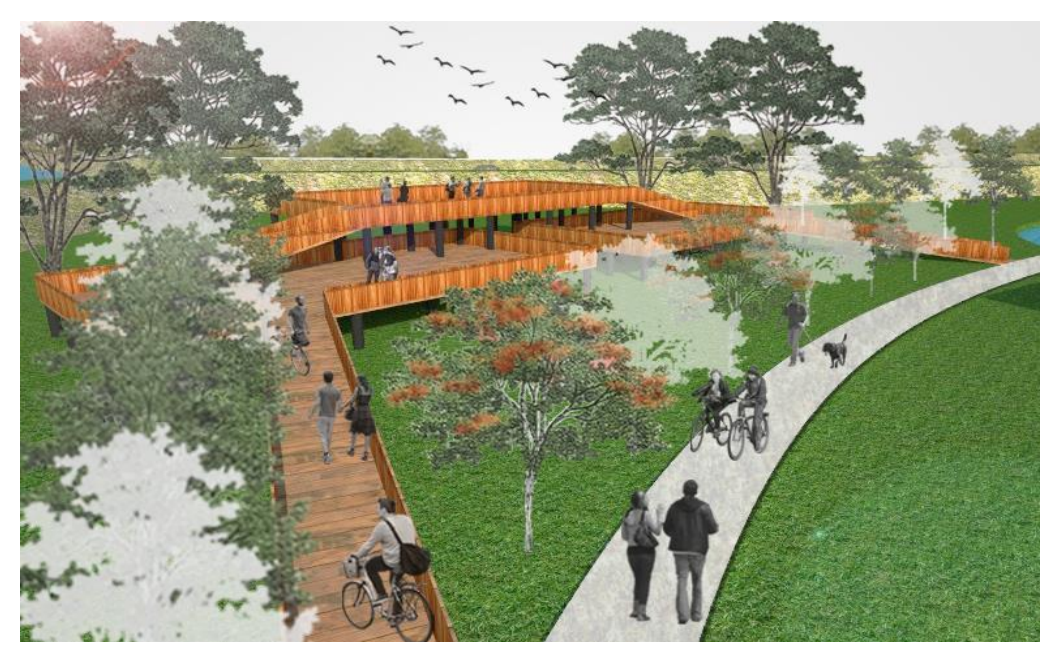

Gambar 8. Ilustrasi Perspektif : Deck Observasi

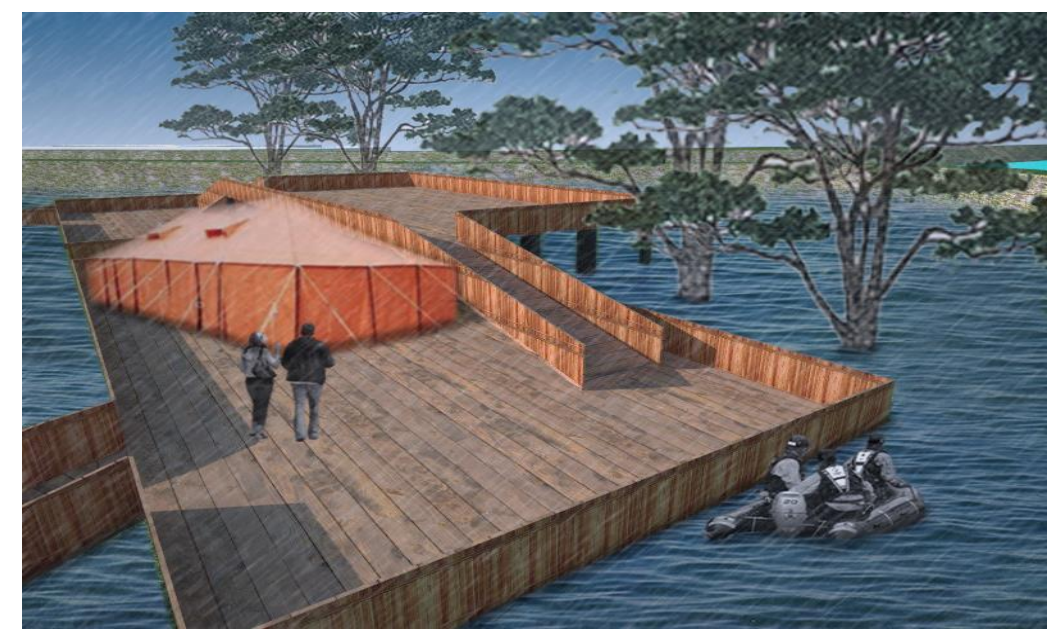

Gambar 9. Ilustrasi Perspektif : shelter dan deck evakuasi

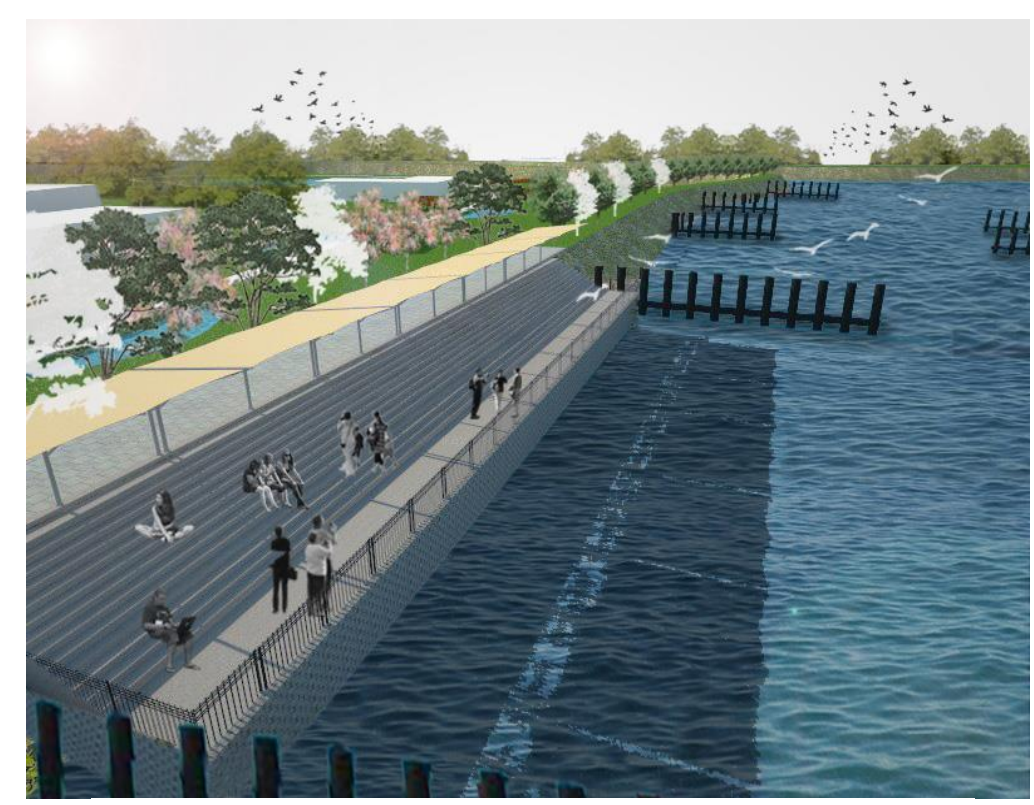

Gambar 10. Ilustrasi Perspektif : Amphiteater 


\subsection{Desain Penanaman}

Konsep revegetasi bantaran sungai Citarum ini lebih kepada konservasi kawasan. Vegetasi akan menjadi komponen pendukung dalam keberlangsungan ekosistem yang mantap di sungai. Komponen vegetasi sungai secara natural akan mendapatkan pupuk dari sedimentasi periodis dari hulu dan tebing, selanjutnya komponen vegetasi ini akan berfungsi sebagai pemasok nutrisi untuk komponen fauna sungai dan juga sebaliknya. Proses ini merupakan pendukung keberlangsungan ekosistem sungai yang memiliki sifat terbuka hulu-hilir. Dengan ekosistem sempadan sungai yang subur, maka sistem konservasi air disepanjang sungai dapat terjaga. (Farid, 2016)

\subsubsection{Desain Penanaman di Desa Bojongsoang, Kabupaten Bandung}

Tanaman yang disajikan di planting plan merupakan jenis tanaman yang terpilih dari segi lanskap, yaitu jenis tanaman konservasi dengan tempat hidupnya misalnya tahan untuk terendam air dan tahan di lahan kering. Jenis vegetasi yang akan ditanam dibagi kedalam beberapa kelompok yaitu pohon tepi sungai yaitu mayoritas pohon yang bisa bertahan hidup saat terendam air, pohon konservasi yaitu pohon yang ditanam di sempadan sungai bertujuan merevegetasi kawasan sungai, vegetasi di retention pond yaitu pohon yang dapat terendam dan tanaman air yang bisa dinikmati keindahan bunganya, pohon berbunga diletakkan di beberapa lokasi sebagai kontras, pohon hutan merupakan jenis tanaman keras yang sesuai dengan ekosistem kawasan.

Tabel 1. Tanaman yang akan ditanam di Desa Bojongsoang, Kabupaten Bandung

\begin{tabular}{|c|c|c|c|c|}
\hline No. & Fungsi & Nama lokal & Nama IImiah & $\begin{array}{l}\text { Jumlah } \\
\text { (Pohon) }\end{array}$ \\
\hline \multirow[t]{6}{*}{1} & Riparian & Gempol & Nauclea orientalis & \\
\hline & Vegetation & Kepayang & Pangium edule & \\
\hline & & Pulai/lame & Alstonia scholaris & 1090 \\
\hline & & Laban & Vitex Pubescan & \\
\hline & & Gayam & Inocarpus fagiferus & \\
\hline & & Balangeran & Shorea balangeran (Korth.) & \\
\hline \multirow[t]{6}{*}{2} & Retention Pond & Sisirihan & Piper aduncum & \\
\hline & Vegetation & Pulai/lame & Alstonia scholaris & \\
\hline & & Laban & Vitex Pubescan & \\
\hline & & Katapang & Terminalia catappa) & 64 \\
\hline & & & Nymphaea lotus & \\
\hline & & & Cyperus papyrus & \\
\hline \multirow[t]{4}{*}{3} & Island Vegetation & Jati belanda & Penorema canescens & \\
\hline & & Katapang & Terminalia catappa) & \\
\hline & & Sempur & Dilenia indica & 59 \\
\hline & & Kecrutan & Spatodea campanulata & \\
\hline \multirow[t]{13}{*}{4} & Conservation & Awi haur & Bambusa vulgaris Schrad. ex J.C & \\
\hline & Vegetation & Jati belanda & Penorema canescens & \\
\hline & & Caringin & Ficus sp. & \\
\hline & & Jengkol & Archidendron pauciflorum (Benth.) & \\
\hline & & & Nielsen & \\
\hline & & Maja & Aegle marmelos (L.) Correa & \\
\hline & & Kecrutan & Spatodea campanulata & 104 \\
\hline & & Jambu air & Eugenia aquea Burm.F & \\
\hline & & Jambu batu & Psidium guajava L. & \\
\hline & & Limus & Mangifera foetida Lour. & \\
\hline & & Nangka & Artocarpus heterophyllus Lamk & \\
\hline & & Awi tali & Gigantochloa apus & \\
\hline & & Awi bitung & Dendrocalamus Asper & \\
\hline
\end{tabular}


Lanjutan Tabel 1

\begin{tabular}{|c|c|c|c|c|}
\hline No. & Fungsi & Nama lokal & Nama IImiah & $\begin{array}{l}\text { Jumlah } \\
\text { (Pohon) }\end{array}$ \\
\hline \multirow[t]{4}{*}{5} & Forest Vegetation & Jabon putih & Anthocephalus cadamba & \multirow{4}{*}{941} \\
\hline & & Sempur & Dilenia indica & \\
\hline & & Bayur & Pterospermum javanicum & \\
\hline & & Gandaria & Bouea macrophylla Griff. & \\
\hline \multirow[t]{2}{*}{6} & Flowering & Kecrutan & Spatodea campanulata & \multirow{2}{*}{80} \\
\hline & Vegetation & Jambu bool & Syzygium malaccense (L.) Merr. & \\
\hline \multirow[t]{6}{*}{7} & Shading & Kupa & Syzygium polycephalum & \multirow{5}{*}{22} \\
\hline & Vegetation & Menteng & Baccaurea racemosa Reinw & \\
\hline & & Kemang & Mangifera kemanga & \\
\hline & & Matoa & Pometia pinnata & \\
\hline & & Bisbul & Diospyros discolor Willd & \\
\hline & Total & & & 2360 \\
\hline
\end{tabular}

\subsubsection{Desain Penanaman di Desa Purwadana, Kabupaten Karawang}

Tanaman yang disajikan di plantingplan merupakan jenis tanaman yang terpilih, yaitu jenis tanaman konservasi dengan tempat hidupnya misalnya tahan untuk terendam air dan tahan di lahan kering. Jenis pohon yang akan ditanam dibagi kedalam beberapa kelompok yaitu pohon tepi sungai yaitu mayoritas pohon yang bisa bertahan hidup saat terendam air, pohon konservasi yaitu pohon yang ditanam di sempadan sungai bertujuan merevegetasi kawasan sungai, pohon di retention pond yaitu pohon yang dapat terendam dan tanaman air yang bisa dinikmati keindahan bunganya, pohon berbunga diletakkan di beberapa lokasi sebagai kontras, pohon hutan merupakan jenis pohon yang dapat ditanam.

Tabel 2. Tanaman yang akan ditanam di Desa Purwadana, Kabupaten Karawang

\begin{tabular}{|c|c|c|c|c|}
\hline No. & Fungsi & Nama lokal & Nama IImiah & $\begin{array}{l}\text { Jumlah } \\
\text { (Pohon) }\end{array}$ \\
\hline \multirow[t]{6}{*}{1} & Riparian Vegetation & Gempol & Nauclea orientalis & \multirow{6}{*}{722} \\
\hline & & Kepayang & Pangium edule & \\
\hline & & Pulai/lame & Alstonia scholaris & \\
\hline & & Laban & Vitex Pubescan & \\
\hline & & Gayam & Inocarpus fagiferus & \\
\hline & & Balangeran & Shorea balangeran (Korth.) & \\
\hline \multirow[t]{6}{*}{2} & Retention Pond & Sisirihan & Piper aduncum & \multirow{6}{*}{68} \\
\hline & Vegetation & Pulai/lame & Alstonia scholaris & \\
\hline & & Laban & Vitex Pubescan & \\
\hline & & Katapang & Terminalia catappa) & \\
\hline & & & Nymphaea lotus & \\
\hline & & & Cyperus papyrus & \\
\hline \multirow[t]{2}{*}{3} & Flowering & Kecrutan & Spatodea campanulata & \multirow{2}{*}{78} \\
\hline & Vegetation & Jambu bool & Syzygium malaccense (L.) Merr. & \\
\hline \multirow[t]{8}{*}{4} & Conservation & Awi haur & Bambusa vulgaris Schrad. ex J.C & \multirow{8}{*}{205} \\
\hline & Vegetation & Jati belanda & Penorema canescens & \\
\hline & & Caringin & Ficus sp. & \\
\hline & & Jengkol & Archidendron pauciflorum (Benth.) Nielsen & \\
\hline & & Maja & Aegle marmelos (L.) Correa & \\
\hline & & Kecrutan & Spatodea campanulata & \\
\hline & & Jambu air & Eugenia aquea Burm.F & \\
\hline & & Jambu batu & Psidium guajava L. & \\
\hline
\end{tabular}


Lanjutan Tabel 2

\begin{tabular}{|c|c|c|c|c|}
\hline No. & Fungsi & Nama lokal & Nama IImiah & $\begin{array}{l}\text { Jumlah } \\
\text { (Pohon) }\end{array}$ \\
\hline & & Limus & Mangifera foetida Lour. & \\
\hline & & Nangka & Artocarpus heterophyllus Lamk & \\
\hline & & Awi tali & Gigantochloa apus & \\
\hline & & Awi bitung & Dendrocalamus Asper & \\
\hline \multirow[t]{4}{*}{5} & Forest Vegetation & Jabon putih & Anthocephalus cadamba & \\
\hline & & Sempur & Dilenia indica & 141 \\
\hline & & Bayur & Pterospermum javanicum & \\
\hline & & Gandaria & Bouea macrophylla Griff. & \\
\hline \multirow[t]{6}{*}{6} & Shading Vegetation & Kupa & Syzygium polycephalum & \\
\hline & & Menteng & Baccaurea racemosa Reinw & \\
\hline & & Kemang & Mangifera kemanga & 42 \\
\hline & & Matoa & Pometia pinnata & \\
\hline & & Bisbul & Diospyros discolor Willd & \\
\hline & Total & & & 1256 \\
\hline
\end{tabular}

\subsubsection{Desain Tehnik Bio-Engineering (Retaining Wall, Groyne, Retention Pond)}

3.3.3.1 Retaining wall

Pembuatan bio-retaining wall ini merupakan perpaduan dari material (beton) dengan groundcover atau bisa menggunakan vetiver. Detail desain dari retaining wall ini terlihat pada gambar 11 dibawah ini.

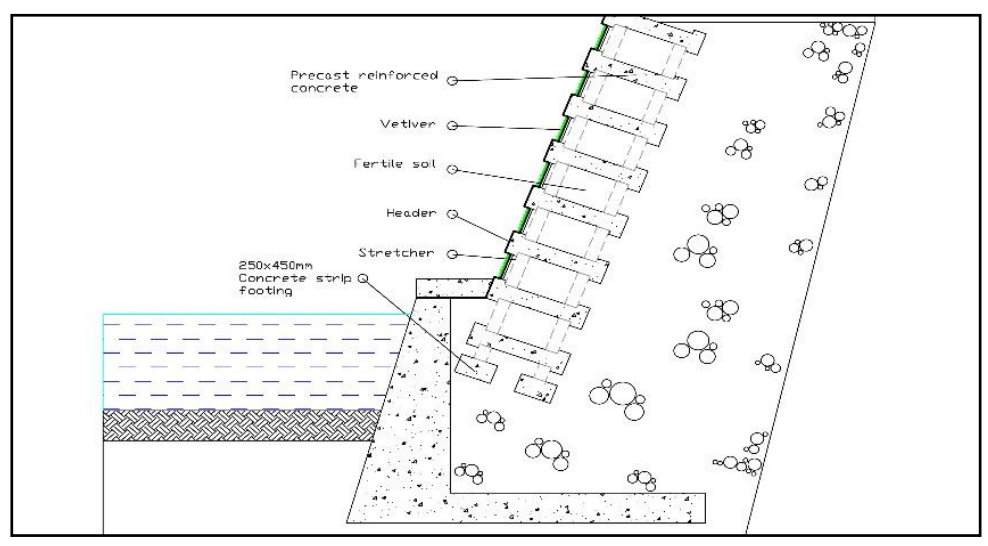

Gambar 11. Detail desain Bio-Retaining wall

\subsubsection{Groyne}

Groyne adalah struktur bangunan yang dibangun di tepi sungai yang berfungsi sebagai penghalau aliran air yang terlalu deras serta dapat membatasi pergerakan sedimen dan mencegah erosi. Groyne biasanya terbuat dari kayu, beton atau batu. Detail desain groyne ditunjukkan pada gambar 12 di bawah ini 


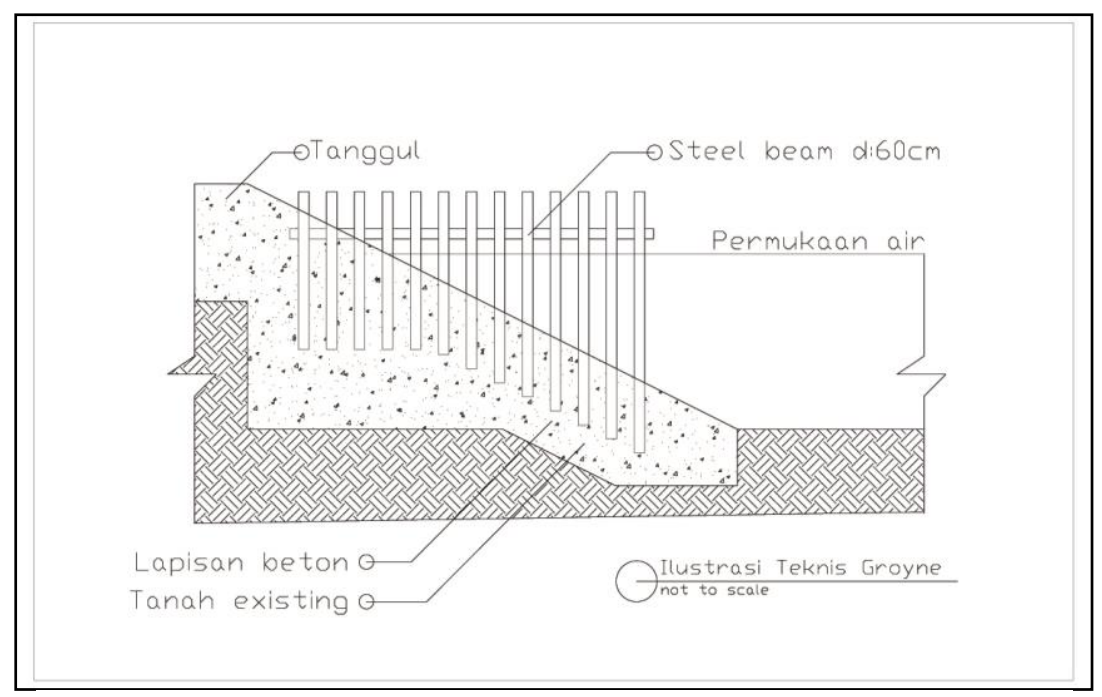

Gambar 12. Detail Desain Groyne

\subsubsection{Kolam Retensi (Retention pond)}

Menurut Heryani (2008), dalam mengelola limpasan air hujan untuk mencegah erosi dan banjir, dapat dilakukan melalui sistem tangkapan hujan (sistem 'pemanenan' hujan) melalui penyediaan fasilitas infiltrasi serta fasilitas penyimpanan (detention/retention). Negara maju seperti Taiwan, Cina, Jerman, Singapura, Korea, Amerika, dan Jepang telah banyak mengaplikasikan teknologi pemanenan hujan dalam upaya mengatasi banjir di perkotaan. Tujuan utama yang ingin dicapai adalah adanya pengaturan yang baik dalam penanganan banjir melalui penyediaan fasilitas untuk meningkatkan infiltrasi air hujan (infiltration facilities) dan mengatur penampungan air (detention facilities) serta penyalurannya. Detail desain kolam retensi ditunjukkan pada gambar 13 di bawah ini

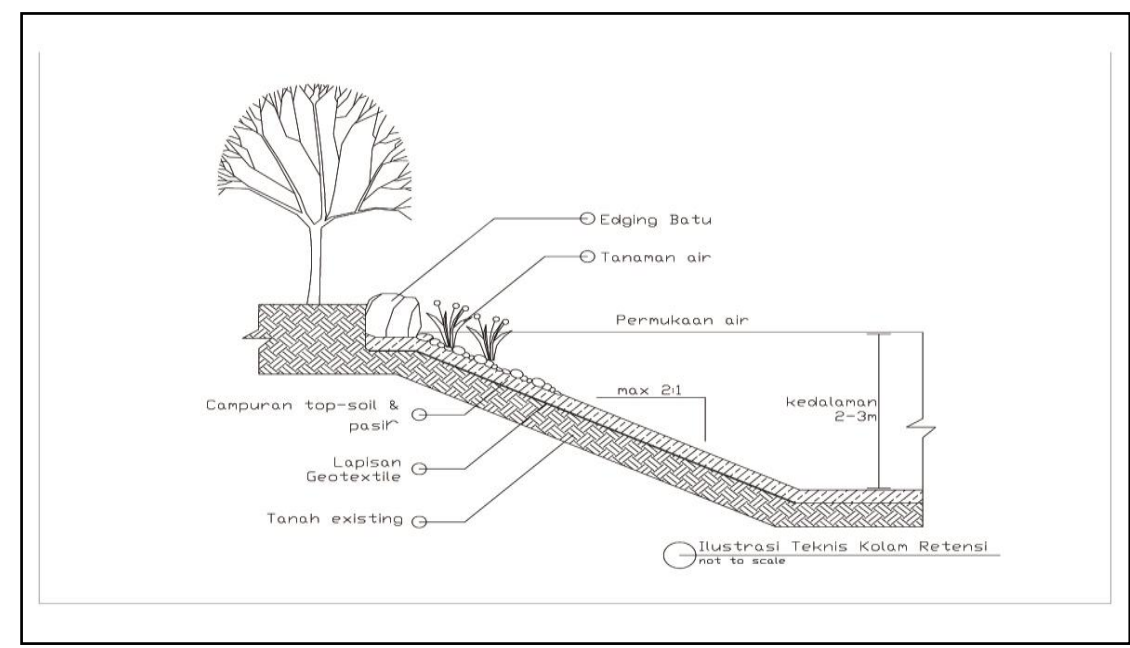

Gambar 13. Detail desain Kolam Retensi

\section{Simpulan}

Upaya rehabilitasi riparian yang dapat dilakukan di bantaran sungai Citarum dengan desain lanskap adalah menata sempadan sungai menjadi area konservasi dan wisata sungai. Upaya teknis konservasi antara lain dengan pengerukan/pendalaman sungai untuk mengurangi sedimentasi sungai, memperbesar daya tampung air, Penambahan tanggul untuk melindungi kawasan pemukiman dari luapan banjir, Revegetasi dengan penanaman tanaman konservasi yang sesuai dengan ekosistem sungai kedua desa, Penambahan kolam retensi untuk menampung air yang berlebih saat banjir, serta pembangunan groyne untuk mengurangi 
laju air. Konsep pemanfaatan lanskap di sekitar bantaran sungai untuk kegiatan publik untuk wisata disaat kondisi banjir maupun tidak merupakan alternatif rehabilitasi yang ideal dalam menampung kebutuhan masyarakat bantaran sungai Citarum.

\section{$5 \quad$ Daftar Pustaka}

Komaruddin, N, 2008. Penilaian Tingkat Bahaya Erosi di Sub Daerah Aliran Sungai Cileungsi, Bogor. Agrikultura. Fak. Pertanian. Universitas Padjajaran.

Widodo, K. Damayanti, V dan Hadi, S. 2012. Perencanaan Lanskap Sungai Kelayan Sebagai Upaya Revitalisasi Sungai Di Kota Banjarmasin Kalimantan Selatan. Jurnal Lanskap Indonesia. 4(1) : 15.

Heryani, N. 2008. Sistem Pemanenan Air Hujan (Rainwater Catchment Systems): Dalam Upaya Pengelolaan Banjir Di Daerah Perkotaan. Buletin DAS. 4(4)

Farid, A. 2016. Studi Kasuspermasalahan Dan Pengelolaansempadan Sungai Brantas. E-Journal. Agriment. $1(1)$

Saridewi, TR, dkk. 2014. Penataan Ruang Daerah Aliran Sungai Ciliwung Dengan Pendekatan Kelembagaan Dalam Perspektif Pemantapan Pengelolaan Usahatani. Forum Penelitian Agro Ekonomi. Vol 32, No 2.

Seftyono, C. 2012. Pembangunan berbasis Waterfront dan Transformasi Konflik di Bantaran Sungai: Sebuah Pemikiran Awal. Jurnal Ilmu Sosial dan IImu Politik Volume 16, Nomor 1, Juli 2012 (75-83)

Zhang, L. 2002. An Evaluation an Urban Riverfront Park, Spokane, WashingtonExperience and Lessons for Designer. Tesis tidak diterbitkan. Washington State University, United States. 